\title{
Corporate parenting and corporate entrepreneurship in media company
}

\section{Ningky Sasanti Munir}

Group of Experts in Strategic Management \& Entrepreneurship, Sekolah Tinggi Manajemen PPM, Central Jakarta, Indonesia

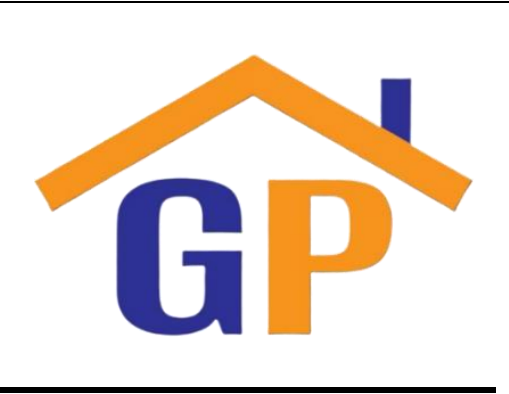

Article History

Received on 4 February 2021

$1^{\text {st }}$ Revision on 18 February 2021

$2^{\text {nd }}$ Revision on 23 February 2021

$3^{\text {rd }}$ Revision on 13 March 2021

Accepted on 16 March 2021

\begin{abstract}
Purpose; The study aimed to understand how the multi-business company creates value through a combined effort of Corporate Parenting (CP) and Corporate Entrepreneurship (CE). The parenting-fit matrix was used to describe $\mathrm{CP}$, while $\mathrm{CE}$ four model was used to describe CE.
\end{abstract}

Research methodology: This study is qualitative applied research using a case study approach conducted on a multi-business media company. Data was obtained primarily through interviews with senior executives representing the holding company and 18 subsidiaries. Questionnaires were also distributed to executives to develop a parenting-fit matrix and CE model.

Results: This study shows that the 18 subsidiaries of the multibusiness company fall under four different cells. The CE model applied at the parent company level is the enabler.

Limitations: The limitation of this study mainly lies in the measurement method's reliability for corporate parenting and corporate entrepreneurship.

Contribution: This study shows that, apart from the parent company, the development of new businesses can also be carried out by the subsidiary companies using the CE producer model.

Keywords: Corporate entrepreneurship, Corporate parenting, Parenting fit matrix, Multibusiness company, Media company

How to cite: Munir, N. S. (2021). Corporate parenting and corporate entrepreneurship in media company. International Journal of Financial, Accounting, and Management, 3(1), 15-26.

\section{Introduction}

Multi-business companies, also known as business groups, have many strategic business units or subsidiaries. In a multi-business company, one company plays a role as a parent or holding company. Such a parent company can intentionally be founded to function as one. Alternatively, one of the existing strategic business units can be assigned as a holding company by shareholders. Goold et al. (2012) wrote that the holding company's role is pivotal in creating value in a multi-business company setting.

Value, in this context, is defined as when the benefit perceived by the corporation is generally higher than the cost or investment spent. Parent companies create value by exercising corporate parenting onto their subsidiaries (Campbell et al., 1995). The end goal of corporate parenting is to ensure that all subsidiaries constantly and healthily grow and pave the way for new businesses to emerge to retain the company's competitive edge in the future.

Value creation can also be obtained by Corporate Entrepreneurship (CE). This refers to entrepreneurial activities such as innovation, exploration, as well as a strategic renewal within an existing company (Corbett et al., 2013). Referring to Wolcott and Lippitz (2007), corporate entrepreneurship is a process where a company develops new business lines that can be different from its core business by leveraging 
the parent company and business group's existing resources market, competence, and other advantages. Through CE, a business group can use creative groups in a company to initiate new businesses and set them to be its future revenue generator and profit center.

Both approaches can create value in multi-business companies, and it is possible for both $\mathrm{CP}$ or corporate parenting and CE or corporate entrepreneurship to be run simultaneously. This study aimed to improve understanding of value creation in multi-business companies through a combination of corporate parenting and corporate entrepreneurship. This study was conducted on a multi-business company with a core business in media, specifically the media business group. Specifically, the study attempts to understand the conception of $\mathrm{CP}$ and $\mathrm{CE}$ in the media business group and how it combines both $\mathrm{CP}$ and $\mathrm{CE}$ in creating value.

\section{Literature review}

\subsection{Corporate Parenting $(\mathrm{CP})$}

In a multi-business company or business group consisting of multiple strategic units, one company will typically act as its parent or holding company. However, in a large-scale business group spanning various news industries, there can be more than one holding company. This holding company may act simply as an investor for its subsidiaries, or it can also hold a more significant role in driving the subsidiaries' strategic direction (Singh \& Salwan, 2015; Victoria \& Dipak, 2014; Abdullah \& Mehmood, 2013).

As it does not always operate as an independent business, the holding company is considered a cost center, bearing most of its administrative expenses. Thus, it is required for the holding company to be able to create value by parenting its subsidiaries properly (Singh \& Salwan, 2015; Abdullah \& Mehmood, 2013; Goold et al., 2012).

According to Campbell et al. (1998) and Goold et al. (2012), holding companies in such arrangements will create value by way of corporate parenting (CP). Goold et al. (2012) suggested three conditions in which holding companies can create value for their subsidiaries.

Firstly, holding companies may take a more active role in overseeing the subsidiaries' business performance, including the possibility to intervene in day-to-day operations. In their research, however, Singh and Salwan (2015), Victoria and Dipak (2014) as well as Lange et al. (2009) have proven that such intervention is not always the best method to conduct $\mathrm{CP}$ on subsidiaries needing performance improvement. This is due to several reasons, but most prominently is the holding company's lack of expertise in the business sector in which the subsidiaries operate in.

The second condition where $\mathrm{CP}$ value creation will improve subsidiaries performance is through the holding company having proper competence, resources, and other attributes required to parent its subsidiaries. A study conducted by Lange et al. (2009) as well as Mishra and Akbar (2007) showed that, other than having required resources such as funds, holding companies are also expected to have strong external access \& connections to support the subsidiaries. A common example is access to key government policymakers, access to funding from external investors, or a high-quality network with partners that own specific technologies to support the subsidiaries.

Furthermore, the third condition that needs to exist to make value creation by $\mathrm{CP}$ possible is for the holding company to have a strong degree of knowledge of the business sector in which its subsidiaries operate and the discipline to be able to avoid value destruction. As explained by Goold et al. (2012) and Campbell et al. (1998), the executives managing the holding company do not always have the necessary experience in the specific industry in which subsidiaries operate. Going back to the study from $\underline{\text { Singh }}$ and Salwan (2015), Victoria and Dipak (2014) also Mishra and Akbar (2007), intervention without the necessary expertise may lead to more chronic issues in the subsidiaries' business.

In order to map parenting fit between a holding company and subsidiaries, Campbell et al. (1998) and Goold et al. (2012) developed the parenting fit matrix. The horizontal axis in the matrix reflects the 
degree of fitness between the parenting opportunities in a parent or holding company's subsidiaries and parenting characteristics. The vertical axis reflects the degree of misfit between the subsidiary's critical success factors and the parent or holding company's parenting characteristics.

Mapping results this way will place each subsidiary into one of five cells, namely heartland, the edge of the heartland, ballast, value trap, and alien territory. Subsidiaries that fall in the heartland and edge of heartland cells saw a strong degree of compatibility between the holding company and the subsidiaries, meaning the holding company can do value creation by helping subsidiaries improve their performance. The holding company understands the subsidiaries' business for subsidiaries in the ballast cell but has limited parenting opportunities to create value. There are many parenting opportunities for subsidiaries in value trap cells in the subsidiaries that the holding company can utilize. However, unfortunately, the holding company has no competence and/or resources needed. Lastly, there is very limited or even no fit between the holding company and its subsidiaries for subsidiaries in alien territory cell, rendering value creation by parent or holding company nearly impossible.

\subsection{Corporate Entrepreneurship (CE)}

Multiple researchers have suggested various definitions of corporate entrepreneurship (CE). For example, in Kuratko and Audretsch (2013), CE is known as the process or entrepreneurial activity done by an individual or a group in an organization to seek solution and opportunities that can assure survival for the company by implementing creative and innovative ideas. CE refers to entrepreneurial conducts such as innovation, exploration, and strategic renewal within an existing company (Corbett et al., 2013). In the context of multi-business companies or business groups, Wolcott and Lippitz (2007) construed corporate entrepreneurship as a company process to develop new businesses different from that of its core business while still utilizing the resource, market, competence, and other benefits of the holding company and its business group. This is in line with a recent study from Han and Park (2017) and Tseng and Tseng (2019), which stated that the innovations resulting from corporate entrepreneurship had produced new products and new business lines. Singh and Salwan (2015), Victoria and Dipak (2014) did not specifically mention corporate entrepreneurship in their research. However, they explained the role of holding companies in creating value for subsidiaries by providing expertise and funding assistance.

Umair et al. (2020) suggested that corporate entrepreneurship can influence a company's performance. Ziyae and Sadeghi (2020) suggested that, principally, CE concept is paramount for large companies to constantly renew themselves to stay up to date in a dynamic market by combining new resources that can change the relationship between the company and its surrounding. In summary, CE is an effort to maintain a company's sustainability. As stated by Han and Park (2017) as well as Tseng and Tseng (2019), innovation in the form of new company development can occur when a company has properly exercised corporate entrepreneurship. As earlier studies from Bierwerth et al. (2015) and Han and Park (2017) showed, companies need to renew even their core business in order to stay relevant in the market or among their customers. By CE, various entrepreneurial activities can be done with less restrain, free from the companies' structural obstacles, to launch innovative new products (Calisto \& Sarkar, 2017) and new businesses (Minafam, 2019). A more recent study from Ziyae and Sadeghi (2020) stated that $\mathrm{CE}$ is an effort for companies to maintain competitiveness and create new competitiveness.

Although it does not explicitly discuss value creation, studies from Victoria and Dipak (2014), Singh and Salwan (2015), as well as Ziyae and Sadeghi (2020) indicated that CE is done in order to get an optimum benefit for cost or investment spent by the company. Various studies have shown that CE is a company's effort to create value, for example, by founding new companies (Wolcott \& Lippitz, 2007; Han \& Park, 2017; Minafam, 2019; ; Tseng \&Tseng, 2019), new processes (Cucculelli \& Bettinelli, 2015; Ravjee \& Mamabolo, 2019), new products (Cucculelli \& Bettinelli, 2015; Calisto \& Sarkar, 2017), innovative new solutions (Wolcott \& Lippitz, 2007; Bierwerth et al., 2015; Chen et al. 2015), new technology use cases (Heavey \& Simsek, 2013; Chen et al. 2015). Those CE outputs will enable companies to enter new business categories or improve subsidiaries' performance within the business group. One of the research issues on $\mathrm{CE}$ is the evaluation or measurement of $\mathrm{CE}$ in the company (Wolcott \& Lippitz, 2007; Kuratko et al., 2014; Han \& Park, 2017). In the context of multi-business 
companies, Wolcott and Lippitz (2007) differentiated CE into four models based on two aspects: the "who" aspect indicating ownership of such creative projects and "authority towards resource" used to support CE.

The result from the four models above showed how a company cultivates CE. They are the opportunist (it is unclear who owns the new business; resource allocation only as needed or ad hoc); the enabler (it is unclear who owns the new business, but there is special resource allocated); the advocate (there is clarity on the new business ownership, but resource allocation only as needed or ad hoc); and the producer (there is clarity on the new business' ownership \& there is special resource allocated).

\section{Research methodology}

This study was conducted on the media (actual name withheld) business group, a media business group with a headquarter in Jakarta, Indonesia. The holding company is PT. Media, Tbk. (public company), a company engaged in advertisement and content-based media. While the group has multiple strategic business units, this research would focus only on 18 companies where the holding company acts as majority shareholder (more than 50 percent). Table 1 lists each core business of the subsidiaries and the year of establishment. The Media Group's business diversification is carried out both organically by establishing new businesses and inorganically acquiring other businesses.

Table 1. Core Business of the media business group's subsidiaries

\begin{tabular}{cccc}
\hline NO & BUSINESS FIELD & $\begin{array}{c}\text { YEAR OF } \\
\text { ESTABLISHMENT }\end{array}$ & CODE \\
\hline $\mathbf{1}$ & TV STATION-A & 1986 & A-TV \\
\hline $\mathbf{2}$ & TV STATION-B & 1992 & B-TV \\
\hline $\mathbf{3}$ & TV STATION-C & 1995 & C-TV \\
\hline $\mathbf{4}$ & TV STATION-D & 2006 & D-TV \\
\hline $\mathbf{5}$ & NEWSPAPER & 1999 & E-NEWS \\
\hline $\mathbf{6}$ & RADIO STATION Network & 2009 & F-RAD \\
\hline $\mathbf{7}$ & MAGAZINE-G & 2002 & G-MAG \\
\hline $\mathbf{8}$ & MAGAZINE-H & 2012 & H-MAG \\
\hline $\mathbf{9}$ & MAGAZINE-I & 2013 & I-MAG \\
\hline $\mathbf{1 0}$ & TALENT MANAGEMENT & 2005 & J-TAL \\
\hline $\mathbf{1 1}$ & PRODUCTION HOUSE & 2005 & K-PH \\
\hline $\mathbf{1 2}$ & PRODUCTION HOUSE (movie) & 2014 & L-PH \\
\hline $\mathbf{1 3}$ & PRODUCTION HOUSE (animation) & 2014 & M-PH \\
\hline $\mathbf{1 4}$ & PRODUCTION HOUSE (new media art, CGI, etc.) & 2015 & N-PH \\
\hline $\mathbf{1 5}$ & EVENT ORGANIZER AND PRODUCTION & 2015 & O-PH \\
& HOUSE (fashion \& life style) & & \\
\hline $\mathbf{1 6}$ & DIGITAL CONTENT (content management) & 2016 & P-DC \\
\hline $\mathbf{1 7}$ & GAME DEVELOPER-QR & 2016 & QR-GAME \\
\hline $\mathbf{1 8}$ & GAME DEVELOPER-S & 2018 & S-GAME \\
\hline
\end{tabular}

The qualitative paradigm is used in this study to gain a deeper understanding of value creation practice by combining parenting fit and corporate entrepreneurship. The characteristic of the research is applied and the type is explorative and descriptive research.

The research data and information were obtained through four methods: studying the company's internal documents, studying publicly available media articles on the media business group published between 2015-2019, interviewing key informants, and sharing questionnaire with selected respondents. The total of key informants is 37 people consisting of the president, director, board members of the holding company, board members of subsidiaries, senior manager in subsidiaries, and corporate secretary. Questions in the questionnaire and interview protocols are developed referring to the parenting fit concept from Campbell et al. (1998) and Goold et al. (2012), as well as the corporate entrepreneurship model from Wolcott and Lippitz (2007). Data and information collected then processes with atlas.ti7 software. The goal of processing is mainly to classify data and information so they have meaning. 
The resulting process using atlas.ti7 is classified data and information about critical success factor of subsidiaries' business, parenting opportunity of holding company to subsidiaries, and holding company's characteristics. Informants are then asked to share their opinion about the fits between holding company's characteristic and parenting opportunities and the misfits between the holding company's characteristic and key success factors of subsidiaries' business. Informants perception is mapped into the parenting fit matrix.

Parenting fit matrix and corporate entrepreneurship identification model of all subsidiaries' mapping result are presented to the board members of holding company which was also attended by board members of subsidiaries and corporate secretary. Inputs and clarification do not significantly change the position of subsidiaries in the parenting fit matrix, neither did they alter the model of corporate entrepreneurship identification. Inputs and clarification are considered as additional information to enrich study results.

\section{Result and discussion}

\subsection{Corporate parenting of media group}

The company acting as a holding company in the media business group is PT. Media, Tbk., a public company, which does not get directly involved in its subsidiaries' operations but acts more like an investment company. PT controls all companies within the media business group. Media, Tbk., as subsidiaries through shareholding and strategic direction from the most prominent shareholder who is also the CEO (Chief Executive Officer) of media business group.

From a written interview with the CEO of the Media Group, discussion with the board of directors at the holding company, as well as from the company's internal data, it is known that the critical success factors of media business group are Content, Awareness, Reach, and Reception or CARR. Content includes program content, program quality, program quantity, and program variation. Awareness relates to promotions, brand, and the image that the program or product of the media business group is known for by its audience, readers, or customers. Reach is how many programs or products are watched by Indonesian customers and the media business group's products' geographic coverage. The last one is Reception, which represents the quality of the broadcast aired, such as picture clarity, audio quality, and anything related to technical broadcast.

Interview with board members in the holding company, board members in the subsidiaries, and senior managers in the subsidiaries showed that the subsidiaries' critical success factors are not different from the holding company. It aligns with the CEO's instruction in the holding company: CARR is the main goal and key performance indicator for all subsidiaries. Interview results followed by surveys using questionnaires on critical success factors showed that, although CARR is a relevant critical success factor for all subsidiaries, each factor's relative importance level is different. For example, among the TV stations (A-TV, B-TV, C-TV, D-TV) and radio (F-RAD) business units, each individual CARR factor is perceived to of the same importance. Meanwhile, the reception factor is less important than other factors in P-DC business unit engaging in content management and J-TAL business unit operating in talent management.

There are four parenting opportunities identified within media 's business units. Firstly, subsidiaries require support in company management. This is mainly among newly acquired subsidiaries, as they have experienced management reshuffle and finance restructuring. It is also the case for newly founded ones. Secondly, a holding company can assist subsidiaries in specific areas such as human resource, marketing, and technology. This is aligned with the holding company's structure that has executives in corporate director level in human resource department and corporate director in the technology, while corporate director in business development department controls marketing aspect. Thirdly, there is a parenting opportunity in the form of an investment fund to improve the quality of the human resource, technology, production facilities, and office buildings. The last opportunity lies in assisting subsidiaries 
in providing access to external networks, such as informants, policymakers (government), potential business partners, and funding.

The holding company has three executive layers; the president director or CEO in charge of the directors, the senior managers or vice presidents, and general managers, followed by the last layer, the functional managers. All executives are a combination of family members, family's best friends, and professionals who follow HR's tight selection mechanism. All executives have at least a master's degree and graduated from reputable universities either from Indonesia or abroad. About $80 \%$ of directors and senior managers in the holding company have at least 10 years of working experience, including a minimum of five years serving as executives in the subsidiaries.

All strategic decisions in the holding company and subsidiaries of the media business group are directly held by board members in the holding company, mainly by the president director. Performance mechanism in holding company is top-down, where PT makes policies and decisions. Media, Tbk. 's board members and done on the executive level and in its business units. All business units have authority only over daily operational management. PT sets the business targets of each business unit. Media, Tbk., and anything related to financial aspects, such as investment expansion of the business units, has to be approved by PT. Media, Tbk. Decisions related to technology are treated similarly.

From the composition of the board members and senior executives in the holding company, it can be inferred that the holding company is highly competent in finance. Other than that, the executives are experienced in media, mainly TV. The executives of the holding company, led by the president director, control the subsidiaries in their strategic direction, finance management, technology management, human resource management, initiating new business units, and synergy between subsidiaries.

Figure 1 maps the subsidiaries relative to the holding company by considering two aspects: the fit of competence or characteristic of parent/holding company and parenting opportunity and the misfit of subsidiaries' critical success factor and characteristics of parent/holding company. It can be seen that five subsidiaries are in heartland cell or heartland businesses. Four of them are subsidiaries engaged in TV station management with different market segments and competitive positions, while another engages in the newspaper business.

Of all those five companies in heartland cell, A-TV (1) is the oldest subsidiary with the biggest revenue contribution among all other subsidiaries. It also serves as the revenue generator in the media business group. Three companies in heartland cell are the oldest companies compared to all other subsidiaries. Top executives in those four companies in heartland cell - A-TV (1), B-TV (2), C-TV (3), and D-TV (4) are also the board members in the holding company. So, although D-TV is a company which was just founded in 2006, the executives previously worked in other TV business units. In total, the five companies in the heartland cell contribute to 76 per cent of the business group's total revenue.

Furthermore, five subsidiaries operate in radio station network management, printed media, and talent management in the edge of the heartland cell. Of all these five companies, the one operating in the talent management business (J-TAL,10) contributes the second-highest revenue compared to all subsidiaries in the media business group, followed by the one operating in radio network management (F-RAD, 6). Of the three subsidiaries in the print media business, one company, I-Mag (9), has performed poorly, scoring continuous losses for five consecutive years. Considering its position as a business at the edge of the heartland category, the parent company has a great opportunity to improve its performance. This company received less attention from the parent company as it operates in a niche market and is being considered for merging with other subsidiaries in the same industry.

Four subsidiaries operating in the production house business are in the ballast and edge of heartland cells. For ballast business, parenting opportunity is relatively limited compared to subsidiaries in the edge of heartland cell or heartland cells. There is only one subsidiary, K-PH (11), which has been able 
to generate profit for five years in a row. The performance of one of the production houses, N-PH (14), has the worst performance among the other four production house units in the media business group.

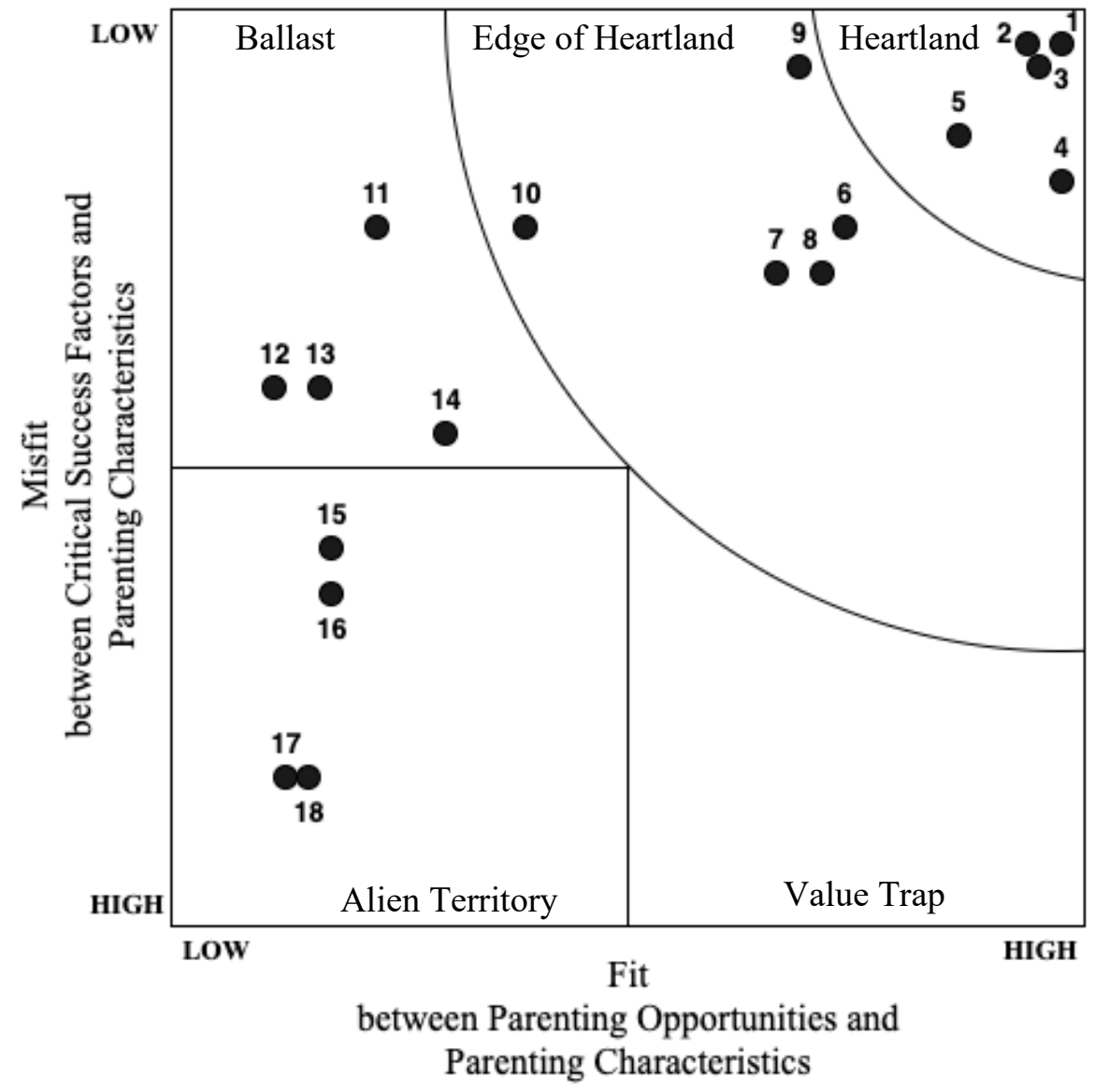

Figure 1. Parenting fit matrix of the media business group Source: Campbell et al. (1998) and Goold et al. (2012)

Four subsidiaries fell under alien territory business. One of them is a new company engaging in event organizing and printed media focusing on fashion and lifestyle. The company in content management, P-DC (16), also fell under alien territory business. Other subsidiaries in this category are two companies operating in the game development business - QR-GAME (17) and S-GAME (18). QR-Game actually consists of two companies: Q-GAME and R-GAME. The two companies were acquired in 2016 to complement the business group's portfolio, but did not operate satisfactorily due to culture incompatibility between the subsidiary and of the Media business group. Since their 2018 merger into one company (QR-GAME), the two companies have shown improved performance and had their executives replaced.

\subsection{Corporate entrepreneurship in the media group}

CE model identification in holding company showed that the holding company uses the enabler model to develop entrepreneurship among its subsidiaries level. According to Wolcott and Lippitz (2007), the enabler model assumes that employees in all organizations will be willing to develop new concepts if given sufficient support. PT. Media, Tbk. as a holding company does this by providing clear criteria to determine which opportunities should be captured, setting clear rules for funding, having a clear decision-making process, and providing concrete and active support from senior management.

Assessment of CE model of all of 18 subsidiaries showed that there are two models; enabler and producer. Table 2 showcases the subsidiaries business category and its CE model. 
Table 2. Subsidiaries business category and corporate entrepreneurship model of media business group

\begin{tabular}{|c|c|c|c|c|}
\hline NO & CORE BUSINESS & CODE & $\begin{array}{c}\text { BUSINESS } \\
\text { CATEGORY }\end{array}$ & CE MODEL \\
\hline 1 & TV STATION-A & A-TV & Heartland & Producer \\
\hline 2 & TV STATION-B & B-TV & Heartland & Producer \\
\hline 3 & TV STATION-C & C-TV & Heartland & Enabler \\
\hline 4 & TV STATION-D & D-TV & Heartland & Enabler \\
\hline 5 & NEWSPAPER & E-NEWS & Heartland & Enabler \\
\hline 6 & RADIO STATION Network & F-RAD & Edge of Heartland & Enabler \\
\hline 7 & MAGAZINE & G-MAG & Edge of Heartland & Enabler \\
\hline 8 & MAGAZINE & H-MAG & Edge of Heartland & Enabler \\
\hline 9 & MAGAZINE & I-MAG & Edge of Heartland & Enabler \\
\hline 10 & TALENT MANAGEMENT & J-TAL & Edge of Heartland & Enabler \\
\hline 11 & PRODUCTION HOUSE & $\mathrm{K}-\mathrm{PH}$ & Ballast & Enabler \\
\hline 12 & PRODUCTION HOUSE (movie) & L-PH & Ballast & Enabler \\
\hline 13 & PRODUCTION HOUSE (animation) & M-PH & Ballast & Enabler \\
\hline 14 & $\begin{array}{l}\text { PRODUCTION HOUSE (new media } \\
\text { art, CGI, etc.) }\end{array}$ & $\mathrm{N}-\mathrm{PH}$ & Ballast & Enabler \\
\hline 15 & $\begin{array}{l}\text { EVENT ORGANIZER AND } \\
\text { PRODUCTION HOUSE (fashion \& } \\
\text { life style) }\end{array}$ & $\mathrm{O}-\mathrm{PH}$ & Alien Territory & Enabler \\
\hline 16 & $\begin{array}{c}\text { DIGITAL CONTENT (content } \\
\text { management) }\end{array}$ & P-DC & Alien Territory & Enabler \\
\hline 17 & GAME DEVELOPER-QR & $\begin{array}{l}\text { QR- } \\
\text { GAME }\end{array}$ & Alien Territory & Enabler \\
\hline 18 & GAME DEVELOPER-S & S-GAME & Alien Territory & Enabler \\
\hline
\end{tabular}

According to Wolcott and Lippitz (2007), the company builds CE by supporting innovative activities with the dedicated fund and management support at an operational level with the producer model. This is reflected in what was done to two subsidiaries in the TV station business, A-TV and B-TV, where new products' development is done in a structured manner with clear rules. Around 70 per cent of new products development (aired and off-air programs) were developed in-house, while other companies develop the rest from the same business group. New products' development is done by internal teams consisting of creative people with various backgrounds. The management provided the team with freedom in conducting their jobs as well as the controlled amount of funds. Management in A-TV and B-TV also prevented conflict between one creative project and another. CE done by A-TV then developed two divisions and spun off to become new business units: J-TAL, engaging in artist management, and K-PH, a production house. As one of the subsidiary in media business group, A-TV still lends assistance to those two new subsidiaries under the coordination of the holding company.

Furthermore, considering the development of TV station business units, the holding company has built a new business unit engaging in production house business: L-PH and M-PH. In the development process of L-PH and M-PH, A-TV and B-TV business units were assigned to supervise the creative process required to create products in programs that will be aired on TV stations. Using CE producer model, both TV station business units directly supported and motivated the "extraordinary" projects.

\subsection{Value Creation Combination of $\mathrm{CP}$ and $\mathrm{CE}$}

As stated by Anand (2005), Abdullah and Mehmood (2013) as well as recent study from Singh and Salwan (2015), as multi-business company, media business group kept expanding its business scale to retain the sustainability of its business and improve its bargaining position in the industry. Business growth is organically done by developing new strategic business units internally, and inorganically by acquiring other companies. Parenting opportunities emerge because subsidiaries are demanded to show good performance and also higher (revenue) contribution for the benefits of the group. Older subsidiaries are demanded to develop innovative products and then develop new businesses by spinning 
off their internal divisions/business units. New subsidiaries are both newly founded and newly acquired. They are demanded to be independent as early as possible and create innovative products to support the core business and the market widely. There are parenting opportunities and, in line with its competence, PT. Media, Tbk. as holding company does CP by helping its subsidiaries under its coordination to perform better performance.

Value creation by holding a company in the media business group is done with $\mathrm{CP}$ and $\mathrm{CE}$. According to four CP models from Wolcott and Lippitz (2007) holding company is implementing an enabler model to conduct value creation in the corporation as a whole. PT. Media, Tbk. has provided fund to assist in the development of innovative products production and new businesses development for its subsidiaries. The holding company does not fully control creative projects' ownership. Interview and survey show that creative projects can be under coordination of the corporate director of the holding company or under the direction of the subsidiaries, the senior managers, or a group of managers from inter-subsidiaries.

Thus, with $\mathrm{CP}$, the holding company has influenced its ability to improve its performance by funding strategy, functional management support, technology investment control, and human resource support. For the sustainability of the whole corporation, the holding company controls the synergy between subsidiaries and the founding of new business units. According to studies by Singh and Salwan (2015), Victoria and Dipak (2014) and a previous study by Lange et al. (2009), in multi-business companies with many strategic business units, the holding company does the parenting by macro controlling. Controlling on the more operational level is done by placing a representative holding company as strategic business unit leader and settling key performance indicators. In the case of the media business group, the key performance indicator is derived from four critical success factors of the media and content industry; the CARR.

With CE, the holding company has influenced the subsidiaries' ability to improve performance mainly through funding strategy, while the subsidiaries' management mainly rules operations. The holding company also monitored the subsidiaries' creative project progress and inter-subsidiary projects for the whole corporate sustainability. media business group has gained not only innovative products but also developed new business units. According to studies by Romero-Martínez et al. (2010) and Kuratko et al. (2014), in multi-business companies with multiple strategic business units, the holding company creates value by controlling strategic aspects at the corporate level and across subsidiaries. Projects which fulfil the key performance indicators derived from CARR can become independent business units.

Back to the parenting fit matrix, it can be seen that value creation by PT. Media, Tbk. mainly can be done in the subsidiaries belong to heartland and edge of heartland business categories. This is because the holding company has sufficient knowledge in the subsidiaries' business, enabling them to make the most available parenting opportunities. The holding company seemed to rely on two subsidiaries, A$\mathrm{TV}$ and $\mathrm{B}-\mathrm{TV}$, to conduct such parenting in the subsidiaries falling under ballast and alien territory business categories. Both subsidiaries have applied CE producer to support creative projects.

\section{Conclusion}

According to the research objectives, a study has been done to investigate value creation combination by corporate parenting (CP) and corporate entrepreneurship (CE) in media multi-business company. By considering three possible conditions enabling value creation by the holding company, it is known that PT. Media, Tbk. as a holding company, can exercise value creation to five subsidiaries in the heartland category and five subsidiaries in the edge of the heartland category. Those ten subsidiaries are companies operating as TV stations, radio stations, newspaper, and magazine business. Of all those ten companies, the only one did not show strong performance. In comparison, five companies in heartland cell contributed to about 76 per cent out of total income in the media business group. 
Eight companies in the media business group are ballast and alien territory business category. Seven of them were established more recently than other subsidiaries, between the year 2014-2018. In the beginning, subsidiaries that operate in the core business support companies in the heartland and edge of the heartland quadrant, so its development followed the development of those companies. In the future, the holding company needs to keep these eight companies to innovate to improve the image and rating of the companies in the heartland and edge of the heartland quadrant.

PT. Media, Tbk. as a holding company will also do value creation by CP by implementing an enabler model to all its subsidiaries in its coordination. There are clear criteria for project development or new business development. The holding company will also provide fund and management support for operational projects. This enabler model matches the tightly controlling character of PT. Media, Inc. exercises when it comes to all strategic direction of all subsidiaries in the media business group.

Assessment of CE model in the subsidiaries showed that there are only two CE models; enabler and producer. Two subsidiaries implement producer model belong to heartland business which is often assigned by holding company to help the growth of newly spun-off businesses.

\section{Research limitations}

This research in the media business group has four limitations. Firstly, from the conceptual side, as mentioned by Goold et al. (2012), the position of subsidiaries in the parenting fit matrix is sufficient to give feedback to the holding company to manage the corporation in general. During the research, there are many subjective statements about three conditions that made value creation in holding company possible: parenting opportunities, critical success factors, and competence or characteristic of holding company. So as stated by Abdullah and Mehmood (2013), one of the parenting fit matrix implementation challenges from Campbell et al. (1998) and Goold et al. (2012) was to gain a more accurate mapping result through a more thorough measuring instrument.

Secondly, as the CP assessment above, it was not easy to identify Wolcott and Lippitz (2007) 's four models accurately. The analysis from interviews and documents study showed two CE models indicators, project ownership and fund allocation. The distinction was not clear in the context of the media business group when it comes to which ones the holding company has full control.

Thirdly, the opportunity to deepen the result more through an interview with the company's owner, the president or CEO, is very limited. The interview was only done once, through written media, for an hour. During the research, it was apparent that the media business group's leader has a significant role and influence in managing the corporation in general.

Lastly, during the research, there was an addition and change in the business structure in the media business group that was followed by leadership/management change in its subsidiaries. This dynamic would have disturbed the data collection and analysis.

\section{Recommendation}

media business group is a dynamic multi-business company that keeps growing and expanding its business scale through organic diversification where subsidiaries are developed internally and inorganic diversification by acquisition. In order to obtain more meaningful results, it is recommended to conduct the research specifically to the groups of companies based on its business categories, such as heartland, edge of the heartland, ballast and alien territory businesses. By doing so, the similarities of the condition that enables value creation can be analyzed deeper.

Considering the business of subsidiaries in media business group, it is known that a multi-business company is a company that grows by diversification in related sectors. Due to that, to understand the combination of value creation through $\mathrm{CP}$ and $\mathrm{CE}$, more can be done with similar research in multibusiness companies with related diversification and its comparison in multi-business company with unrelated diversification. 
Finally, by considering the significant role of the top leader of the media business group, it is also recommended to do quantitative research to see the influence of leadership towards value creation in multi-business company. Quantitative research can also be conducted to see the influence of the diversification type (related, unrelated) towards value creation in multi-business companies.

\section{References}

Abdullah, H. H., and Mehmood, K.K. (2013). Corporate parent value addition and challenges. MiddleEast Journal of Scientific Research, 15 (11). 1606-1617. DOI: 10.5829/idosi.mejsr.2013.15.11.11640, Retrieved from https://www.researchgate.net/publication/282283695_Corporate_Parent_Value_Addition_and Challenges

Anand, Bharat N. 2005. Strategies of related diversification. Harvard Business School Publishing, 9705-481.

Bierwerth, M., Schwens, C., Isidor, R., and Kabst, R. (2015). Corporate entrepreneurship and performance: A meta-analysis. Small Business Economics, 45(2), 255-278. DOI: 10.1007/s11187-015-9629-1 Retrieved from https://www.researchgate.net/publication/269516885_Corporate_Entrepreneurship_and_Perfo rmance A Meta-Analysis

Calisto, M. D. L., \& Sarkar, S. (2017). Innovation and corporate entrepreneurship in service businesses. Service Business, 11(3), 581-600. http://dx.doi.org/10.1007/s11628-016-0321-6

Campbell, A., Goold, M., and Alexander, M. (1995). Corporate strategy: The quest for parenting advantage. Harvard Business Review, March-April pp. 120-132.

Chen, Y., Wang, Y., Nevo, S., Benitez-Amado, J., and Kou, G. (2015). IT capabilities and product innovation performance: The roles of corporate entrepreneurship and competitive intensity. Information \& Management, 52(6), 643-657. https://doi.org/10.1177/2158244020962779

Corbett, A., Covin, J. G., O'Connor, G. C., and Tucci, C. L. (2013). Corporate entrepreneurship: Stateof-the-art research and a future research agenda. Journal of Product Innovation Management, 3(5): 812-820. http://dx.doi.org/10.1111/jpim.12031

Cucculelli, M., and Bettinelli, C. (2015). Business models, intangibles and firm performance: Evidence on corporate entrepreneurship from Italian manufacturing SMEs, Small Business Economics, 45(2), 329-350. DOI: 10.1007/s11187-015-9631-7

Goold, M., Campbell, A., and Alexander, M. (2012). Strategy for the corporate level: Where to invest, what to cut back and how to grow organizations with multiple divisions. John Wiley \& Sons, Ltd. DOI:10.1002/9781119208013

Han, J. and Park, C. (2017), Case study on adoption of new technology for innovation: perspective of institutional and corporate entrepreneurship, Asia Pacific Journal of Innovation and Entrepreneurship, $11(2), \quad 144-158 . \quad$ Retrieved from https://www.emerald.com/insight/content/doi/10.1108/APJIE-08-2017-031/full/html

Heavey, C., and Simsek, Z. (2013). Top management compositional effects on corporate entrepreneurship: The moderating role of perceived technological uncertainty. The Journal of Product Innovation Management, 30(5), 837-855. DOI: 10.1111/jpim.12033

Kuratko, D. F., and Audretsch, D. B. (2013). Clarifying the domains of corporate entrepreneurship. International Entrepreneurship and Management Journal, 9(3), 323-335. DOI:10.1007/S11365-013-0257-4 Retrieved from https://www.semanticscholar.org/paper/Clarifying-the-domains-of-corporate-KuratkoAudretsch/fedacb2e20e0c40e4ef52213bbdb9cc99dad092f

Kuratko, D. F., Hornsby, J. S. and Covin, J. G. (2014). Diagnosing a firm's internal environment for corporate entrepreneurship. Business Horizons, 57(1), 37-47. DOI:10.1016/J.BUSHOR.2013.08.009 Retrieved from https://www.semanticscholar.org/paper/Diagnosing-a-firm\%27s-internal-environment-forKuratko-Hornsby/3adfaf4e8a1d62d69b6713aa4a4ff7afe3986a10

Lange, D., Boivie S., and Henderson, A.D. (2009). The parenting paradox: How multibusiness diversifiers endorse disruptive technologies while their corporate children struggle. Academy of Management Journal, 52(1), 179-198. DOI: 10.5465/AMJ.2009.36462006 
Minafam, Z. (2019). Corporate entrepreneurship and innovation performance in established Iranian media firms. Ad-Minister, (34), 69-92. doi:http://dx.doi.org/10.17230/ad-minister.34.4

Mishra, A., and Akbar, M. (2007). Parenting advantage in business groups of emerging markets. Vision - The Journal of Business Perspective, 11(3), 1-10. DOI: 10.1177/097226290701100302

Ravjee, B., and Mamabolo, M. A. (2019). The impact of corporate entrepreneurship on service innovation: A case of a South African banking institution. The Southern African Journal of Entrepreneurship and Small Business Management, 11(1) http://dx.doi.org/10.4102/sajesbm.v11i1.155

Romero-Martínez, A. M., Ortiz-de-Urbina-Criado, M., \& Ribeiro Soriano, D. (2010). Evaluating European Union support for innovation in Spanish small and medium enterprises. The Service Industries Journal, 30(5), 671-683.

Singh, N., and Salwan, P. (2015). Contribution of parent company in growth of its subsidiary in emerging markets: Case study of Maruti Suzuki. The Journal of Applied Business and Economics, 17(1), 24-44. Retrieved from https://search.proquest.com/scholarlyjournals/contribution-parent-company-growth-subsidiary/docview/1726782919/se2? accountid $=130508$

Tseng, C. and Tseng, C. (2019). Corporate entrepreneurship as a strategic approach for internal innovation performance. Asia Pacific Journal of Innovation and Entrepreneurship, 13(1), 108120 Retrieved from https://www.emerald.com/insight/content/doi/10.1108/APJIE-08-2018$\underline{0047 / f u l l / h t m l}$

Umair, A., Umrani, W. A., Umer, Z., Rajput, S. M., \& Aziz, T. (2020). Corporate entrepreneurship and business performance: The mediating role of employee engagement. Sage Open, 10(4) http://dx.doi.org/10.1177/2158244020962779

Victoria, M., and Dipak, B. (2014). Evolving relationship between the parent and subsidiaries in multinational companies. Advances in Management, 7(2), 1-15. Retrieved from https://search.proquest.com/scholarly-journals/evolving-relationship-between-parentsubsidiaries/docview/1502695827/se-2?accountid=130508

Wolcott, R.C. and Lippitz, M.J. (2007). The four models of corporate entrepreneurship. MIT Sloan Management Review, 49(1), 74-82. Retrieved from https://sloanreview.mit.edu/article/thefour-models-of-corporate-entrepreneurship/

Ziyae, B. and Sadeghi, H. (2020). Exploring the relationship between corporate entrepreneurship and firm performance: The Mediating effect of strategic entrepreneurship. Baltic Journal of Management. 16(1), 113-133 https://doi.org/10.1108/BJM-04-2020-0124 